\title{
Biodynamic timber sheet pile walls: vegetation retaining structure
}

\author{
Abhijith Kamath $^{1}\left[\right.$ ] Wolfgang Gard ${ }^{1} \cdot$ Jan-Willem Van de Kuilen ${ }^{1,2}$
}

Received: 12 October 2019 / Published online: 4 September 2020

(c) The Author(s) 2020

\begin{abstract}
Timber sheet pile walls are widely used for the protection of stream banks in different parts of the world. However, there is a tendency to create more sustainable types of stream banks not only because exploitable wood is more difficult to obtain, but also because of disturbance to the natural habitat of plants and animals due to hard embankments. In the Netherlands alone, about $2500 \mathrm{~km}$ of engineered timber sheet pile wall embankments exist, primarily made with tropical hardwood, besides an even much larger amount of 'non-engineered' small-size timber-based embankments. As an alternative, the authors propose to use a mixed timber sheet pile-vegetation system, where locally available timber can be applied in combination with natural vegetation. Unlike the usual bioengineering scheme, vegetation is not seen as an element, which could replace the timber sheet piles. Instead, a new perspective is tested, where the vegetation is included as a 'structural' element which can even counteract the consequences of time-dependent biological degradation of the timber sheet pile. By doing so, both long-term durability as well as reliability of the stream bank is improved. A comprehensive design strategy was developed based on well-established sub-models from the literature on plant growth, root reinforcement as well as timber damage accumulation. The timber sheet pile wall-vegetation system is illustrated in an example case study. Preliminary analysis including only the mechanical reinforcement of vegetation shows that there is a decrease in moment and shear acting on the timber sheet pile with growth of the vegetation. Consequently, the damage accumulation due to load duration effects on the timber decreases and the service life of the system increases. Thus, using vegetation in combination with highly degradable timber could possibly negate the need for using hardwood timber, or more generally, save resources that are currently used for these structures.
\end{abstract}

\section{Introduction}

Timber sheet pile walls are an efficient way for embankment design along streams and canals. They are widely used in countries with extensive delta areas. Examples for the design of sheet pile walls can be found in Broms (1988) and Tan (2005). However, stabilizing embankments does not necessarily mean the use of engineered structures techniques. A study of the evolution of bioengineering techniques by Evette et al. (2009) shows evidence of the use of wood species to stabilize river banks dating back to the sixteenth century. Prominent examples include that of King Frederick William 1 of Prussia, who ordered to plant willows on

Abhijith Kamath

A.C.Kamath@tudelft.nl

1 Biobased Structures and Materials, Faculty of Civil Engineering and Geosciences, Delft University of Technology, Delft, The Netherlands

2 Chair of Wood Technology, Technical University of Munich, Munich, Germany riverbanks and of Dugied in France, who suggested to plant exotic species like Chinese varnish tree (Toxicodendron vernicifluum (Stokes) F.A. Barkley) and white mulberry (Morus alba L.) to form dense barriers (Evette et al. 2009; Dugied 1819). Ecological engineering techniques have been well recognized and implemented in many riverbank restoration and protection projects (Li et al. 2006; Anstead and Boar 2010; Anstead et al. 2012; Evette et al. 2009). The first and second principle of ecological engineering as stated by Bergen et al. (2001) requires that the designs produced mimic natural structures and are site-specific. The concepts of energy efficiency, independence of design and functional requirements are addressed in the third and fourth principle.

Ecological engineering involves the use of live evapoplants in combination with inert material to protect and conserve soil. The plant roots are expected to provide mechanical reinforcement to the soil while the evapotranspiration provides hydrological reinforcement. Tardío and Mickovski (2016) used live plants in combination with wood to develop a dynamic soil bioengineering scheme, which was validated on a slope stabilized by crib wall and 
willow. González-Ollauri and Mickovski (2014) developed an integrated model taking into account the hydrological and mechanical effects of vegetation that could be used with simple input parameters. Different types of bioengineered structures were analysed by Fernandes and Guiomar (2016) some 20 years after construction. The effect of riparian vegetation in stabilizing streambanks was studied and quantified in the pioneering works of Thomas and Pollen-Bankhead (2010), Simon and Collison (2002), Pollen-Bankhead and Simon (2009) etc.

Riverbank degradation has societal and environmental impacts. Timber sheet piles are often used as stream bank protection structure. Timber sheet piles are considered environmentally friendly compared to other conventional solutions like concrete walls or steel sheet piles. Sometimes, tropical hardwoods, which have better resistance to decay, may not be locally available and have to be imported. For example, the Netherlands has about $2400 \mathrm{~km}$ of engineered timber sheet pile, while it has very little exploitable tropical hardwoods (Van de Kuilen and Van der Linden 1999). Thus, there is a need for an alternative solution, which involves locally available material and at the same time fits into the scope of ecological engineering. A timber sheet pile-vegetation composite stream bank protection structure is proposed in this paper as an alternative to currently employed conventional methods. Vegetation, due to the presence of roots, provides additional cohesion to the embankment soil (Simon and Collison 2002), thereby mechanically reinforcing the soil. This increase in soil strength is reflected in a reduction in the earth pressure acting on the timber sheet pile. The mechanical reinforcement of the soil with growth of vegetation would thus result in a reduction of bending moments and shear forces acting on the sheet pile over time. Among other factors, the service life of timber depends on the load duration and biological degradation. Thus, the additional mechanical reinforcement provided by roots which results in a decrease in bending moment and shear force would in turn result in decreasing duration of the load effect in the timber. Damage accumulation models are used in timber research to asses the residual strength of timber. Strength development with time under long-term mechanical loads, when combined with biological deterioration in a damage accumulation model makes it possible to predict the service life of timber structures (Van de Kuilen 2007). The effects of slow biological degradation of wood in air-water-soil conditions is compensated by the reduction in load acting on the timber sheet pile due to the presence of vegetation in a timber sheet pile-vegetation system. Researchers have pointed out the need for including dynamic nature of vegetation roots in the slope stability analysis (Stokes et al. 2009). To the best of the authors' knowledge, there exists no study focusing on a bio-engineered stream bank retaining structure, which takes into account the positive specific characteristics of the riparian vegetation root growth and the dynamic nature of the roots. The basic methodology adopted in any bioengineered structure is the design of load sharing and transfer between the inert material and the vegetation. The load transfer might eventually lead to the vegetation supporting the slope and the inert material slowly decaying away without compromising the structural safety of the embankment. The authors would like to see the effect of vegetation from a different perspective, namely the vegetation is included as a "structural" element, increasing the service life of the system. As mentioned earlier, one of the key issues faced in countries like the Netherlands is the non-availability of high decay resistant hardwood. Thus, in this study, vegetation reinforcement is considered as an element, which reduces the damage accumulation over time in a sheet pile, thus providing a valuable contribution to the combined load carrying capacity, as the reduction in timber load carrying capacity is counteracted by the, over time, increasing resistance of the soil because of root growth. The increase in service life is demonstrated through a case study. The experimental study provided by Zhang et al. (2018) is used to determine the mechanical reinforcement provided by the roots, due to the quality of the input data. The damage accumulation model used for the timber components is based on the work by Caulfield (1985), Van der Put (1986, 1989), Foschi and Yao (1986), and Van de Kuilen (1999a, 2007). These damage accumulation models have been verified experimentally in a number of studies (Van de Kuilen 1999a, b; Rosowsky and Bulleit 2002).

\section{Methods}

\subsection{Model components}

It is aimed to understand the development of a timber sheet pile-vegetation system and characterize the effect of vegetation on the time-dependent load carrying capacity of the system. The combination of different model components is shown in Fig. 1. After introducing the components of the model, first a cantilever sheet pile was evaluated (Case 1), see Fig. 2. Second, the timber sheet pile-vegetation system was analysed in a time framework with growth of vegetation and damage accumulation on the sheet pile (Case 2).

Root distribution models provide the quantity (mass) of roots at different depths from the surface. A suitable root distribution model for riparian ecosystems was employed in the model. Knowing the root distribution at each time period, $\Delta t_{i}$, the additional cohesion due to roots was estimated for that time period. Any change in cohesion of the backfill would reflect in a change in lateral earth pressure and hence in a change in bending moment and shear forces acting on a sheet pile. The variations in bending moment and 
Fig. 1 Flow chart of model components

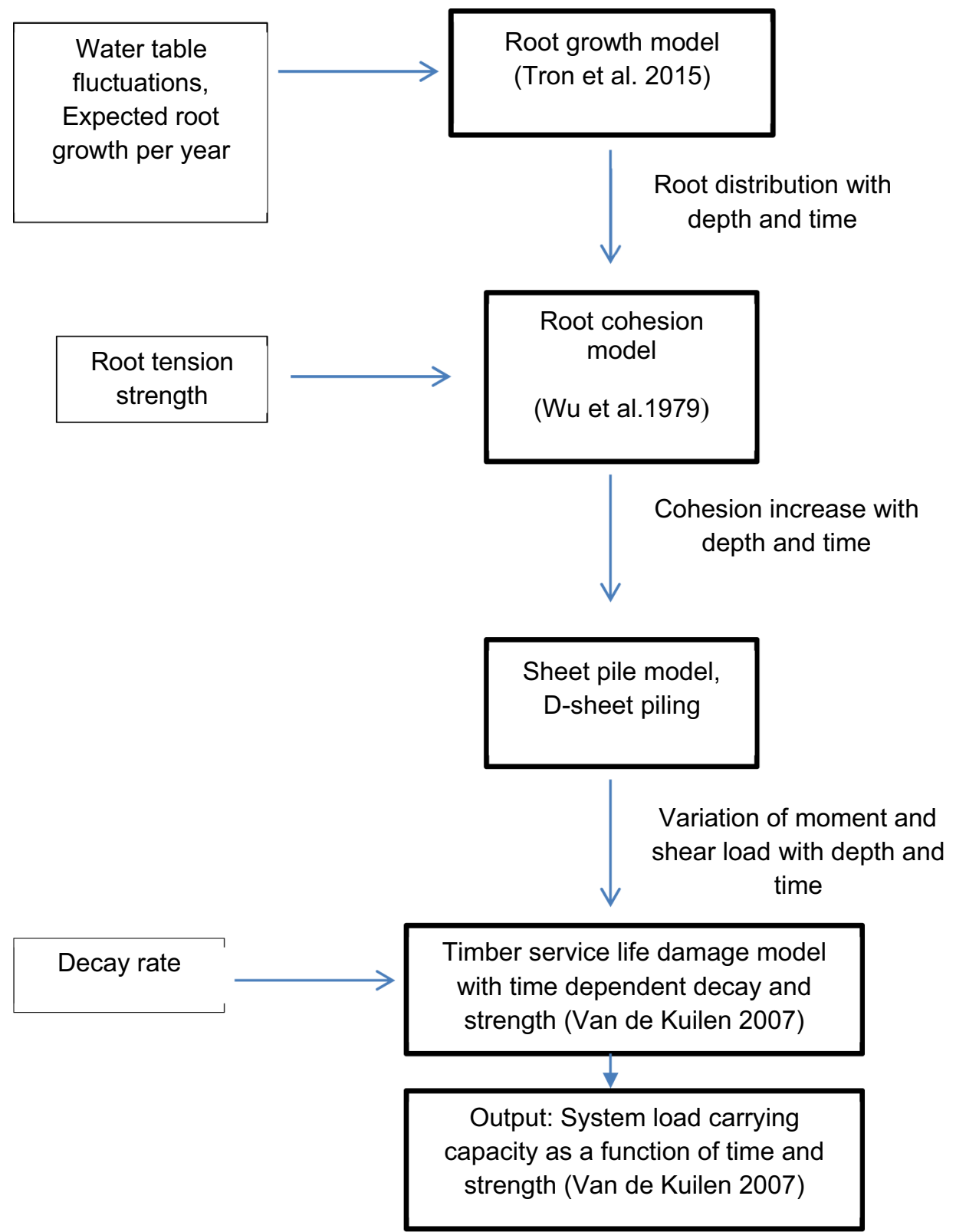

shear stresses experienced by the timber sheet pile are the key parameters in the evaluation of the effect of vegetation on the sheet pile. Any change in moment would in turn result in a change in the required thickness of the sheet pile structure. Thus, the required thickness of the sheet pile would become a time-dependent parameter. On the other hand, the sheet pile is subjected to biological degradation and effects of load duration, especially when using locally less available durable softwoods. This would result in a reduction in the thickness of the sheet pile and hence the moment carrying capacity and shear resistance. All the component models are described briefly in the next section. The behaviour and evolution of the timber sheet pile-vegetation system is illustrated through an example application.

\subsection{Root growth model}

The models for root distribution proposed by Laio et al. (2006), Preti et al. (2010) and Schenk (2008) are mainly intended to be used in situations where the vegetation uptake relies on water infiltrating into the soil (Tron et al. 2015). In riparian regions, ground water is the main source of nutrients and water for vegetation (Zeng et al. 2006), unlike in other situations, where the nutrient availability decreases with depth. The roots can concentrate in the top regions due to lack of oxygen resulting from high water table or can grow deep to reach the water table to exploit necessary nutrients and water. To model the effects of riparian vegetation on soil reinforcement, it is required to adopt a root distribution 


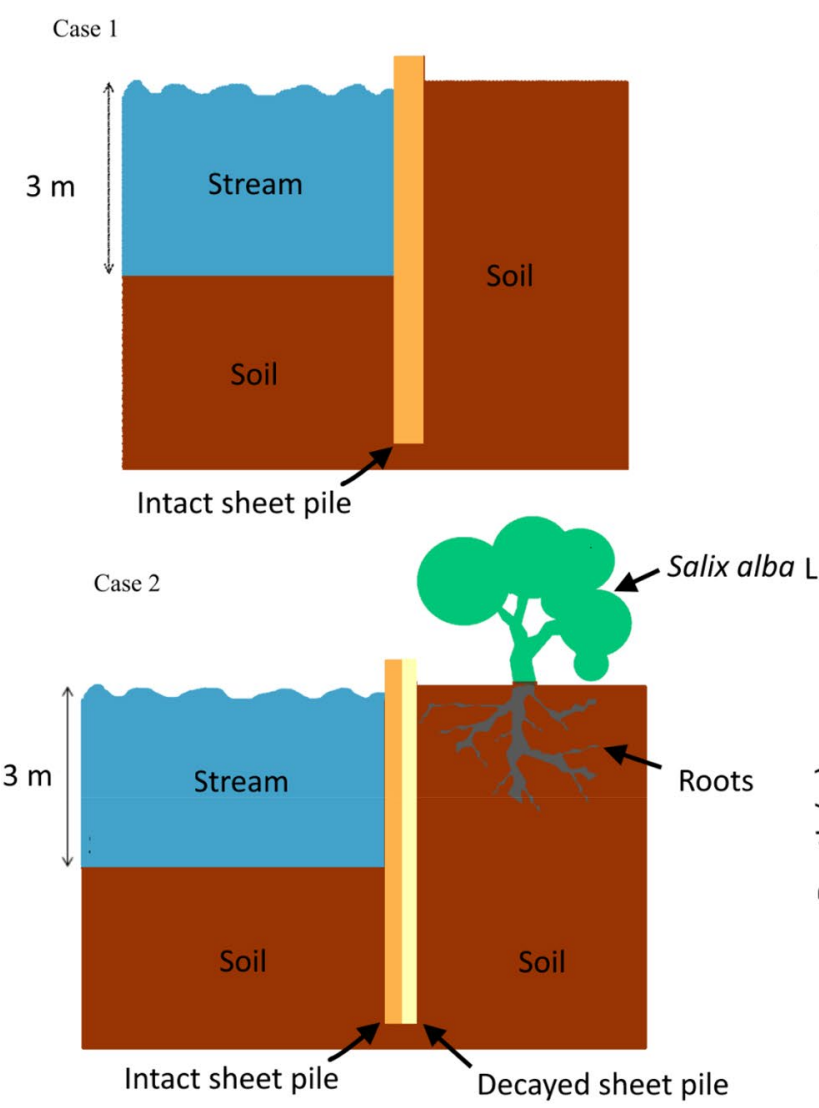

Fig. 2 Case 1, a 3-m-high stream bank retained by a sheet pile made of timber, which has low resistance to decay. Case 2, the same stream bank retained by a low resistance to decay timber sheet pile-vegeta-

model, which takes into account the above-mentioned situations. Tron et al. (2014) developed a stochastic analytical model for finding the vertical root distribution in ecosystems where rainfall infiltration is not the main source of plant water uptake, see Eqs. 1-4:

$$
\begin{aligned}
& \overline{\mathrm{r}}(\mathrm{z})=\frac{2 \theta(\mathrm{z}) \mathrm{k}(\mathrm{z})}{\theta(\mathrm{z})+\theta(\mathrm{z}) \mathrm{K}(\mathrm{z})+1-\mathrm{k}(\mathrm{z})} \\
& \theta(\mathrm{z})=\frac{\beta(\mathrm{z})}{\gamma}
\end{aligned}
$$

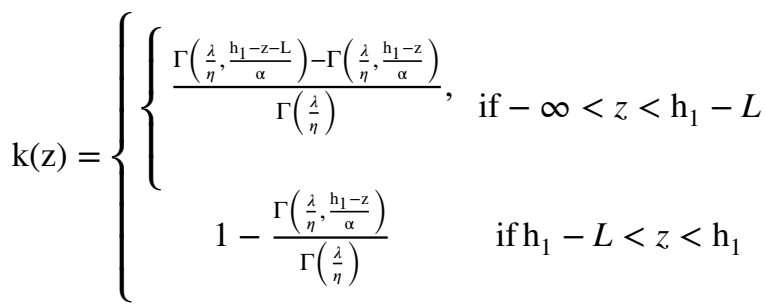

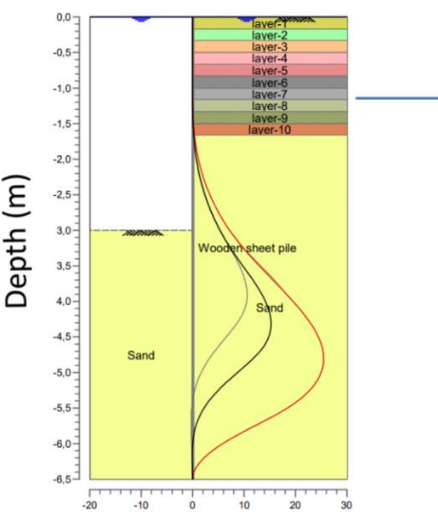

tion system. A decayed sheet pile and grown vegetation are shown in Case 2. Corresponding bending moment acting on the sheet pile is shown on the right side

$\alpha=\frac{\check{\alpha}}{h_{2}}$,

where $\bar{r}(z)$ is the normalized root mass at depth $\mathrm{z}$, and to obtain real root mass, $\bar{r}(z)$ is multiplied by maximum root mass. At a certain depth from the water table, the root growth is enhanced and its range depends on the water table fluctuation. $k(z)$ is the probability that a depth $\mathrm{z}$ falls in the optimal root growth zone, the zone below the surface where the root growth is favoured. The range of the optimal root growth zone is represented by a root box of width $L$. The water table jumps, which are considered instantaneous at daily time scale, are taken into account using the mean depth of pulses $\check{\alpha} . \beta(z)$ represents the growth rate of roots and $\gamma$ represents decay rate of roots. $\lambda$ is the mean rate of stochastic instantaneous rise of water level, $h_{2}$ is the depth of water table at driest periods, $\eta$ is the water level decrease in time, and $h_{1}$ is depth of the root box.

According to this model, the roots concentrate on the upper layers if the variability of the water table is high, and 
deeper roots are found when the variability of the water table is less.

\subsection{Root cohesion model}

The most widely used root reinforcement model developed by Wu et al. (1979) assumes that all roots grow perpendicular to the shear surface and they all break simultaneously. If the root distribution and tensile strength are obtained, this model can easily be implemented and applied here. Even though this model results in overestimation (Pollen and Simon 2005; Thomas and Pollen-Bankhead 2010) of the additional cohesion assessed, successful application and observation have been reported (Mickovski et al. 2008; González-Ollauri and Mickovski 2014). The parameters k' and $\mathrm{k}$ " are used to correct the overestimation. $\mathrm{k}$ " is the ratio between Wu et al. (1979) model and the fiber bundle model developed by Pollen and Simon (2005). k' is the parameter to account for the overestimation related to the assumption that roots are perpendicular to the shear surface.

$C_{r}(\mathrm{z})=k^{\prime} * k * R A R(z) * T_{r}$,

where $C_{r}(z)$ is the additional cohesion $(\mathrm{kPa})$ due to vegetation, $\operatorname{RAR}(z)$ is the root area ratio, dimensionless, and $T_{r}$ is the average tensile strength of the root (MPa).

\subsection{Sheet pile model}

D-sheet piling (Visschedijk and Trompille 2011) is a tool with a graphical interactive interface used to design sheet pile walls and horizontally loaded piles. The sheet pile is modelled as an elasto-plastic beam and uniform or variable stiffness could be defined along the beam axis. Initial horizontal stress is estimated using Jáky's equation (Jaky 1948) and additional stresses using Boussinesq's stress distribution theory (Boussinesq 1885). Soil stiffness is modelled as a series of discrete, independently acting multilinear springs, forming an elastic foundation for a beam. Options to optimize length are also included in the standard module. The elastic stiffness and an estimated depth of the sheet pile are given as input parameters for the sheet pile. Cohesion, internal friction angle, and density are given as input parameters for the soil. It is possible to define different soil layers with varying cohesion. The moment, shear force and displacement of the sheet pile are obtained as output from the D-sheet piling software.

\subsection{Timber service life model}

Timber service life modelling is generally conducted for time-dependent structural safety evaluation, also referred to as damage accumulation for long-term loading conditions. The prediction of rate of decay of wooden members and hence their structural load carrying capacity as a function of time is key to any bioengineered structure. For an ideal bioengineered structure, herein referred to as timber sheet pile-vegetation combinations, the load transfer and load sharing design depend on the ability to accurately predict the contribution of the roots and the sheet pile to the system with time. Effects due to variation in load and resistance determine the time-dependent behaviour of the sheet piles. Timber service life models are also referred to as damage accumulation models, and a number of approaches can be found in the literature (Van der Put 1986; Foschi and Yao 1986; Gerhards and Link 1987). These models basically describe the development of the strength over time under the influence of mechanical loads. In these models, cross sections do not change over time, for instance by assuming that the wood material properties over time are not influenced by decay and the cross section remains constant. Modification of a linear exponential damage model (see Caulfield 1985; Van der Put 1986; Gerhards and Link 1987), for changing material properties and cross sections can be found in Van de Kuilen (2007) and Van de Kuilen and Gard (2012) with examples of deteriorating timber piles in foundations and cracked timber beams. To include the time-dependent reduction in the load carrying capacity of the timber when physical and biological deterioration takes place, Eq. (6) is given as:

$\frac{\mathrm{d} \alpha}{\mathrm{dt}}=\exp \left\lceil-\mathrm{a}+\frac{\mathrm{b} \sigma(\mathrm{t})}{\mathrm{f}_{\mathrm{s}}(\mathrm{t})}\right\rceil$,

where $\frac{\mathrm{d} \alpha}{\mathrm{dt}}$ is rate of damage and $\alpha$ can vary from 0 to 1 , with 0 representing no damage and 1 representing structural failure, $\sigma(\mathrm{t})$ represents the history of load variation ( $\mathrm{N}$ or $\mathrm{Nmm}$ ), and $\mathrm{f}_{\mathrm{s}}(\mathrm{t})$ represents the variation in load carrying capacity with time ( $\mathrm{N}$ or Nmm). Often, instead of plotting the development of $\alpha, 1-\alpha$ is plotted, indicating the relative residual load carrying capacity. The moment carrying capacity varies with time due to reduction in the cross section, but also because the strength of the outer layers may be reduced because of biological decay. Thus, the total rate of change of the effective sectional moment of area $\in_{I}$ and change in effective cross-sectional area $\in_{A}$ resisting shear can be written as:

$$
\begin{aligned}
& \in_{I}(t)=\left(1-\frac{2 \delta}{b}\right)\left(1-\frac{2 \delta}{t}\right)^{2} \\
& \epsilon_{A}(t)=\left(1-\frac{2 \delta}{b}\right)\left(1-\frac{2 \delta}{h}\right),
\end{aligned}
$$

where $\delta$ is the rate of decay per year, $b$ is the width and $h$ is the thickness of the sheet pile.

Thus, the time-dependent area $A_{t}$ and moment of area $W_{t}$ could be written in terms of original area $A_{0}$ and original moment of inertia $W_{0}$ as: 
$W_{t}=W_{0} \in_{I}$

$A_{t}=A_{0} \in_{A}$.

The time-dependent sectional moment of inertia, area resisting shear, moment carrying capacity and shear resistance can be evaluated from the above equation while the bending moment and shear acting on the sheet pile could be obtained from the D-sheet piling software.

\subsection{Case study}

To illustrate the model and understand the effect of vegetation on the damage induced on the sheet pile, a case study at the stream bank location in Huairuou District, Beijing China was chosen. The heavy rainfall in July 2016 resulted in the destruction of many parts of the bare bank and riverbank hardening projects (Zhang et al. 2018). This location is ideal for the case study, not only due to the readily available biomass measurements of living brush mattress (Salix alba L.) for 5 and 7 years (Zhang et al. 2018), but also because of the increasing popularity in ecological engineering measures to protect stream banks in China. Please note that the same model framework can be applied to any location in the Netherlands, provided sufficient quality data is available. The detailed soil description is also available for the location. A 3-m-high stream bank made of sandy loam and loamy sand is to be retained. The internal friction angle of the soil was chosen to be $30^{\circ}$ with no cohesion. The bulk density of the embankment soil was taken as $18 \mathrm{kN} / \mathrm{m}^{3}$. A timber sheet pile retaining structure (Case 1) was compared with a timber sheet pile-vegetation structure (Case 2) for a design life of 20 years, see Fig. 2.

\section{Results and discussion}

\subsection{Root distribution model}

For any location, the root distribution model given by Tron et al. (2015) needs to be calibrated for the prediction of the root distribution with depth. The temporal variation of Salix alba L. 'Tristis' for 5 years given by Zhang et al. (2018) was used to calibrate the parameters of the root distribution model. A preliminary assessment of the root distribution and root growth rates given by Zhang et al. (2018) implies that significant root growth (about 12 percent of the maximum root growth) is observed to a depth of $0.9 \mathrm{~m}$. Further, it should be noted that the root density is higher at $0.2-0.4 \mathrm{~m}$, which implies the availability of water for plants at these depths and that the water table fluctuates sharply. Thus, a relatively higher root growth window $(\mathrm{L}=0.5)$ and $\alpha=0.3$ were chosen to represent these conditions. A value of 2.0 was chosen for $\lambda / \eta$ to fit the calibration better for the first 5 years. The root growth rate given by Zhang et al. (2018) is input in the model for the prediction of the root distribution for the 7-year period. Tron et al. (2015) suggested that the impact of $\theta(z)$ on the root profile is low. For prediction of root biomass, the $\theta(\mathrm{z})$ was estimated from the data provided by Zhang et al. (2018) and for the prediction of root biomass after 7 years, a constant value of 1 was assumed throughout the depth.

The parameters of the root distribution model were calibrated with the abovementioned parameters for the root distribution of 5 years. With the calibrated model parameters and growth rates for the 6 th and 7 th year, a prediction of the root distribution was made. The observed and the predicted root distributions show good conformity, which implies that the adopted parameters and the model are able to capture the root distribution at the location with good accuracy (Fig. 3).

To estimate the root distribution in the future, it is necessary to know the temporal increase in maximum root biomass. This parameter will not be known to the designer during the design stages. Thus, like for many soil engineering problems, estimation of maximum root biomass or root growth rate will rely on the experience, understanding and judgement of the designer. Future research needs to focus on estimating the growth rate and obtaining field data for developing more precise root growth models. In this case study, a maximum root growth rate of $30 \mathrm{~g}$ per year per plant was assumed for the first 20 years. This assumption falls within the range of minimum biomass of energy willow root balls reported in Juliszewski et al. (2015). It is beyond the scope of this article to analyze the impact of the assumption of $30 \mathrm{~g}$ per year of root biomass growth on the system stability. The root distribution as expected is different from the waterlimited ecosystems; it peaks at $0.3 \mathrm{~m}$ and does not decrease exponentially with depth.

\subsection{Mechanical strength model}

Since the precise root biomass density is not available, an approximate root biomass density of $0.8 \mathrm{~g} / \mathrm{cm} 3$ was assumed to calculate the volume of roots, as used by other analytical models (González-Ollauri and Mickovski 2014). Considering the unit volume of soil, and that all roots crossed the slip surface, the root area ratio was calculated as volume of roots per volume of soil (Genet et al. 2008). Even though some studies (Smyth et al. 2013) used analytical models to estimate the fine and coarse roots from the total root biomass, they were not used here due to a lack of proof of applicability of these models to all conditions. Hence, the average tensile strength as used by other researchers (Tardío and Mickovski 2016; GonzálezOllauri and Mickovski 2014) in analytical modelling was 
Fig. 3 Calibration of the root distribution model for the 5 th year and prediction of the root distribution model for the 7th year

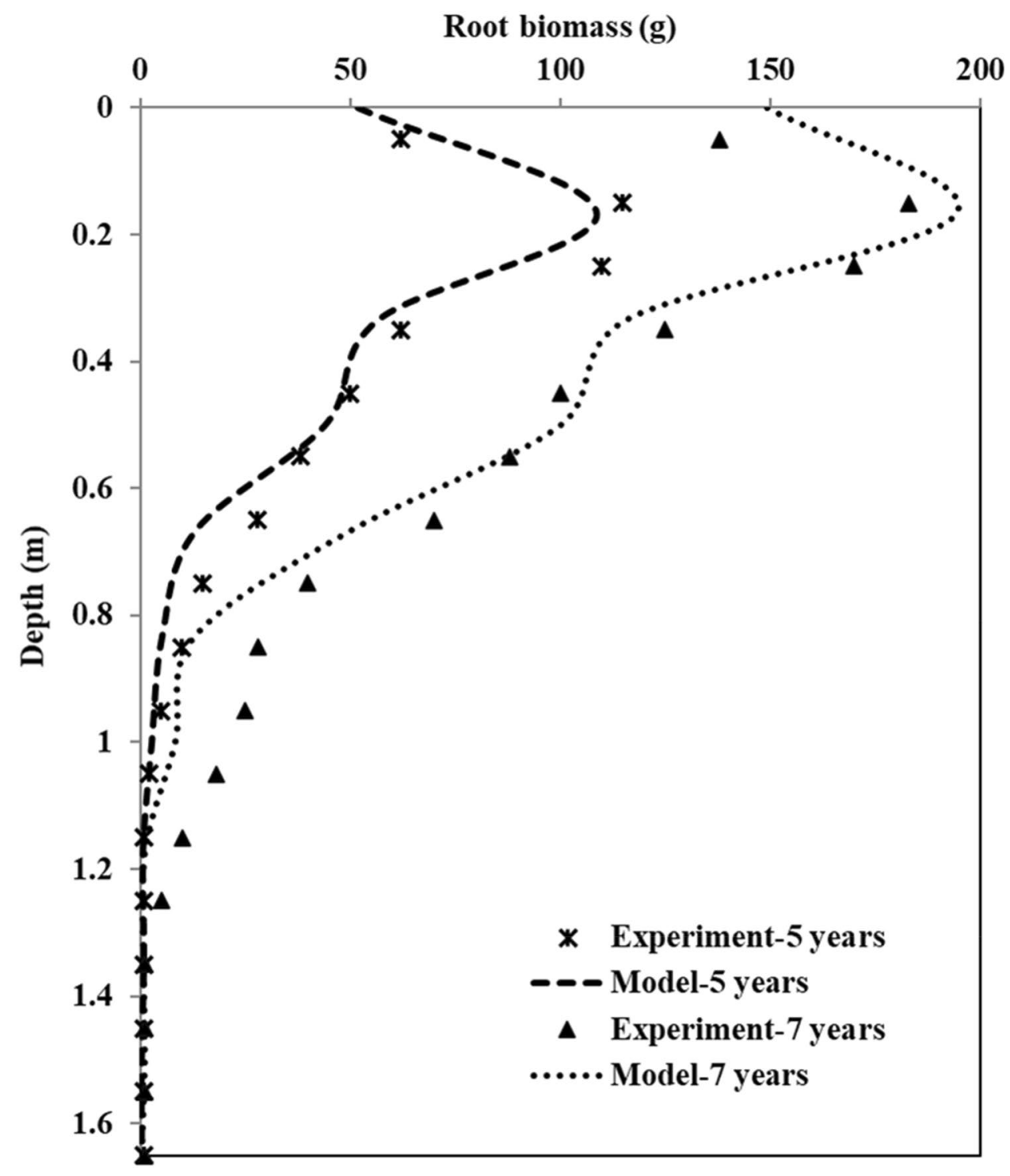

adopted here. An average tensile strength of $32 \mathrm{MPa}$ for Salix alba L. 'Tristis' was adopted. For this case study, the values of k' and k" were assumed as unity.

The variation of the additional cohesion due to roots is shown in Fig. 4. The calculated additional cohesion due to root cohesion of 7 years is more conservative compared with the experimental results obtained by Zhang et al. (2018). A maximum additional cohesion of $23.5 \mathrm{kPa}$ due to the presence of roots was observed at a depth of $0.16 \mathrm{~m}$ in 7 years, which increased to $40 \mathrm{kPa}$ in 20 years (see Fig. 4). Even though the input values of the root distribution model and root cohesion values were estimated from the literature, obtained values of additional cohesion due to the presence of roots are on the conservative side compared with the experimental results obtained by Zhang et al. (2018).

\subsection{Timber service life model}

The maximum bending moment (M) acting on the sheet pile in Case 1 was taken from the output of D-sheet piling (Visschedijk and Trompille 2011). The initial bending moment $\left(\mathrm{M}_{0}=21.54 \mathrm{kNm}\right)$ experienced by the sheet pile before the growth of vegetation (Fig. 5) will be the maximum bending moment (M) acting on the sheet pile in Case 1. Sheet piles are often made of the wood species azobé (Lophira alata), which is assigned to strength class D70 of European standard EN 338 (Van de Kuilen and Blass 2005). This corresponds to a characteristic bending strength 
Additional cohesion due to roots $(\mathrm{kPa})$

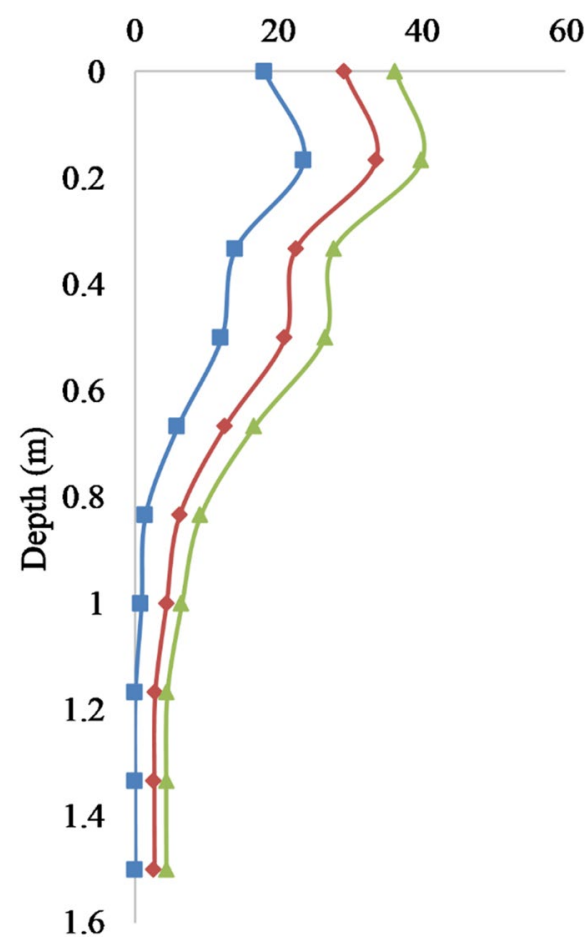

Fig. 4 Variation of additional cohesion provided by the roots over the years for different depths

of $\mathrm{f}_{\mathrm{m}}=49.5 \mathrm{MPa}$ and shear strength of $1.5 \mathrm{~N} / \mathrm{mm}^{2}$ after taking into account the modification factor and safety factors for material property $\left(\gamma_{\mathrm{M}}=1.3 \mathrm{EC} 5, \mathrm{k}_{\mathrm{ls}}=1.15\right.$ for load-sharing and $\mathrm{k}_{\omega}=0.8$ for high moisture content application). The influence of long term loading is excluded, since it is now incorporated in the damage model. A sheet pile with reference width of $1 \mathrm{~m}$, and thickness $0.075 \mathrm{~m}$ was chosen to retain the soil. The decay rate of the entire timber sheet pile was assumed to be $-0.001 \mathrm{~m}$ ( $1 \mathrm{~mm} /$ year $)$. The parameters of the timber damage accumulation model, $a=21, b=25$ were adopted for the estimation of the time to failure line for timber beams, in line with Murphy et al. (1987). Two different approaches could be used to estimate the contribution of decayed section modulus. The more conservative approach is to neglect the contribution of the decayed section completely. For a more realistic estimate, the decayed section can be assumed to have a certain percentage of the initial strength $\left(f_{0}\right)$ (Van de Kuilen 2007). In this paper, two cases are presented and calculated with respect to their expected service life: (i) the decayed section has a remaining strength $f_{\mathrm{r}}$ which is $20 \%$ of the initial strength: $f_{\mathrm{r}}=0.2 f_{0}$, and (ii), the decayed section has no remaining strength at all: $f_{\mathrm{r}}=0$.

With an assumed upper limit decay rate of $1 \mathrm{~mm} /$ year for azobé in soil conditions as an example case, the sectional modulus was estimated to decrease by more than $48 \%$ in 20 years. This results in a decrease in the moment
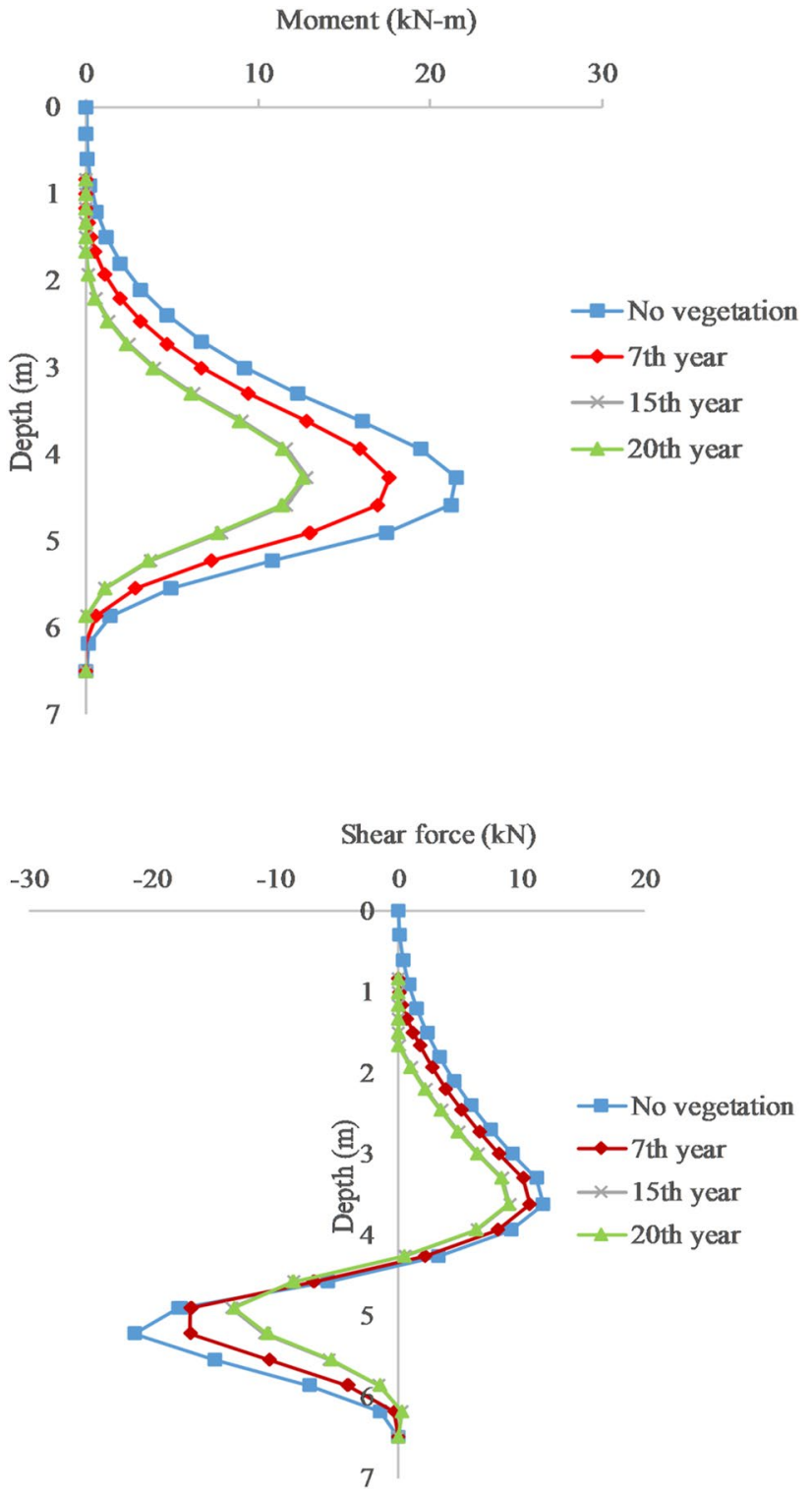

Fig. 5 Time-dependent variation of bending moment (top) and shear force (bottom) acting on the entire length of the timber sheet pile over the years

carrying capacity of the sheet pile. When the decayed area is assumed to have no contribution, the damage $\alpha$ reaches the value of 1 in the 18th year. Thus, structural failure of the sheet pile system is expected after 18 years. However, when the decayed wood is assumed to have a remaining strength of $0.2 f_{0}$, the residual moment capacity reaches a value of 1 in the 23rd year (see Fig. 6). Thus, when, $f_{\mathrm{r}}=0.2 f_{0}$, it can be seen that structural failure is postponed by 5 years, equivalent to an increase in the expected service life by $28 \%$.

The cross sectional area resisting the shear capacity reduces by over $28 \%$ in 20 years. The residual shear carrying capacity is seen to reduce to zero in the 47 th year 


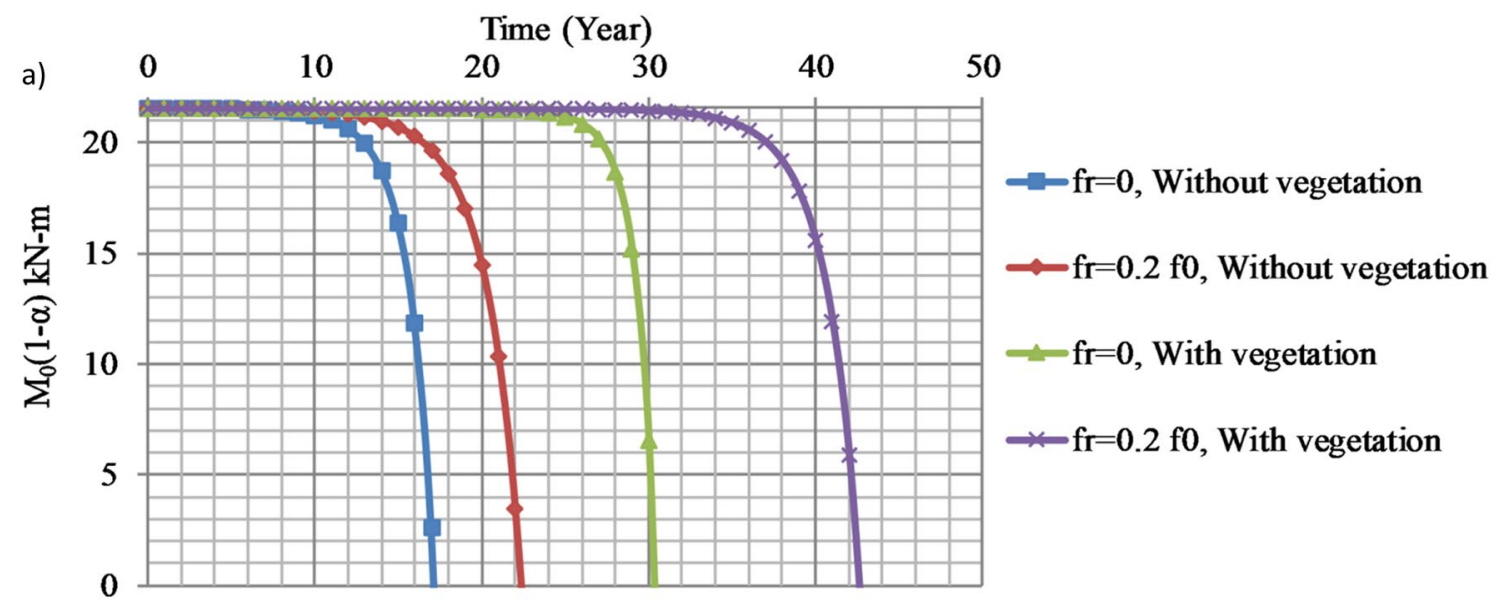

b)

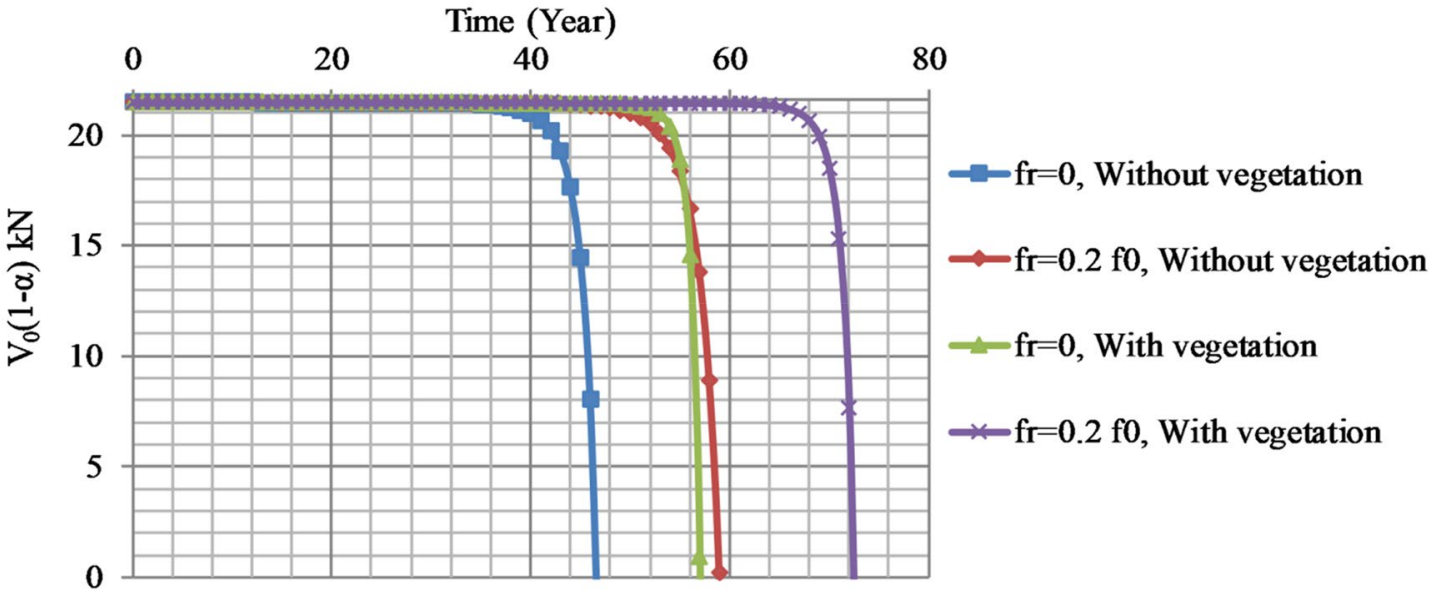

Fig. 6 Evolution of damage accumulation on the timber sheet pile with and without vegetation. a Variation of $\mathrm{M}_{0}(1-\alpha)$ with time due to damage accumulation; $\mathbf{b}$ variation of $\mathrm{V}_{0}(1-\alpha)$ with time due to damage accumulation

when no contribution of the decayed part is assumed. Under the condition $f_{\mathrm{r}}=0.2 f_{0}$, the sheet pile wall will have failed completely by the 59th year (see Fig. 6). It can, thus, be concluded that the bending moment becomes the critical parameter in the case of a design life of 20 years.

\subsection{Sheet pile-vegetation system}

The additional cohesion due to the roots was represented as layers of increased cohesion in the streambank embankment. In total, 10 layers of thickness $0.16 \mathrm{~m}$ each were created and assigned to the corresponding cohesion value obtained from the mechanical model. The moment distribution in each year from the 7th year to the 20th year was calculated, and it can be seen that the moment acting on the sheet pile decreases with the growth of the vegetation. The bending moment without vegetation, Case 1 , is $21.54 \mathrm{kNm}$, reduces to $17.6 \mathrm{kNm}$ in 7 years and further reduces to $12.62 \mathrm{kNm}$ after 20 years (Case 2), (Fig. 5). The shear load in Case 1 is $21.44 \mathrm{kN}$ and it reduces to $13.36 \mathrm{kN}$ in 20 years in Case 2 . This reduction in bending moment and shear could be included as the time-dependent loading in the timber damage model. The new damage coefficient and subsequent residual moment and shear carrying capacity after inclusion of the time-dependent loading $\sigma(\mathrm{t})$ were estimated. Applying $f_{\mathrm{r}}=0.2 f_{0}$ and the new time-dependent loading (bending moment and shear), the damage coefficient $\alpha$ at 20 years is $6 \mathrm{e}-04$ in bending and $6 \mathrm{e}-06$ in shear. Further, when $f_{\mathrm{r}}=0$, the damage coefficient $\alpha$ takes a value of 0.0018 in bending and $7 \mathrm{e}-06$ in shear. This implies that the sheet pile-vegetation system has only very minor damage. As compared to the sheet pile only system, the residual moment and shear carrying capacity of the sheet pile-vegetation system do not reduce to zero in the intended service life of 20 years. In other words, the effect of vegetation is such that a longer service life could be expected.

For instance, for the condition $f_{\mathrm{r}}=0$, the sheet pile-vegetation system is estimated to be damaged completely or 
the damage coefficient reaches the value of one in 31 years, in case $f_{\mathrm{r}}=0.2 f_{0}$, it reaches 43 years in bending. Consequently, a prolonged service life of approximately 13 years and 20 years is expected when the vegetation reinforcement is included in the calculations. In shear, an extra service life of 10 years $\left(f_{\mathrm{r}}=0\right)$ and 14 years $\left(f_{\mathrm{r}}=0.2 f_{0}\right)$ is expected in a timber sheet pile-vegetation compared to the retaining structure of timber sheet pile alone.

\section{Conclusion}

Biodynamic timber sheet pile wall—vegetation system has been shown to have a prolonged service life in comparison to a normal timber sheet pile wall structure. The research in the field of soil bio-engineering is focussed on designing the entire structure in such a way that the vegetation may take over the structural performance of the inert material like timber in the long term, in case this material is degrading. Realizing the fact that the strength degradation of timber is dependent on the variation of load acting on it with time, a model framework was proposed taking the vegetation development as well as duration of load effects in timber and its biological degradation into account. With decreasing load acting on the timber sheet pile with the growth of vegetation, the damage accumulation on the sheet pile decreases, thereby increasing the design life of the timber sheet pile. This is illustrated through a case study, where the vegetation is seen to increase the service life of the timber sheet pile by decreasing the load acting on it with time. The system leads to the possibility of designing timber sheet pile walls with smaller dimensions, or with less durable material. The structural safety of the 'combined' system of sheet pile and vegetation can be estimated using the proposed procedure. An example study shows the positive effects of plant root growth behind the timber sheet pile on the expected service life.

Acknowledgements The work described in this publication was supported by the European Commission H2020 Framework Programme through the grant to the budget of the Marie SkłodowskaCurie European Training Networks (ETN) project TERRE, Contract H2020-MSCA-ITN-2015-675762.

\section{Compliance with ethical standards}

Conflict of interest On behalf of all authors, the corresponding author states that there is no conflict of interest.

Open Access This article is licensed under a Creative Commons Attribution 4.0 International License, which permits use, sharing, adaptation, distribution and reproduction in any medium or format, as long as you give appropriate credit to the original author(s) and the source, provide a link to the Creative Commons licence, and indicate if changes were made. The images or other third party material in this article are included in the article's Creative Commons licence, unless indicated otherwise in a credit line to the material. If material is not included in the article's Creative Commons licence and your intended use is not permitted by statutory regulation or exceeds the permitted use, you will need to obtain permission directly from the copyright holder. To view a copy of this licence, visit http://creativecommons.org/licenses/by/4.0/.

\section{References}

Anstead L, Boar RR (2010) Willow spiling: review of streambank stabilisation projects in the UK. Freshw Rev 3(1):33-48

Anstead L, Boar RR, Tovey NK (2012) The effectiveness of a soil bioengineering solution for river bank stabilisation during flood and drought conditions: two case studies from East Anglia. Area 44(4):479-488

Bergen SD, Bolton SM, Fridley JL (2001) Design principles for ecological engineering. Ecol Eng 18(2):201-210

Boussinesq J (1885) Application des potentials à létude de léquilibre et du mouvement des solides élastiques. (Application of potentials to the study of equilibrium and motion of elastic solids) (In French). Gauthier-Villars, Paris

Broms BB (1988) Design and construction of anchored and strutted sheet pile walls in soft clay. In: Second international conference on case histories in geotechnical engineering. 20

Caulfield DF (1985) A Chemical Kinetics Approach to the Duration of Load Problem in Wood. Wood Fiber Sci 17(4):504-521

Dugied PH (1819) Projet de boisement des Basses-Alpes: Présenté a S.E. Ministre secrétaire d'état de l'intérieur. (Basses-Alpes afforestation project: presented to HE the Minister Secretary of State for the Interior) (In French). Imprimerie royale, Paris

Evette A, Labonne S, Rey F, Liebault F, Jancke O, Girel J (2009) History of bioengineering techniques for erosion control in rivers in Western Europe. Environ Manag 43(6): 972

Fernandes JP, Guiomar N (2016) Simulating the stabilization effect of soil bioengineering interventions in Mediterranean environments using limit equilibrium stability models and combinations of plant species. Ecol Eng 88:122-142

Foschi RO, Yao ZC (1986) Another look at three duration of load models. In: CIB-W18, Proceedings of the 19th Meeting, Paper 19-9-1, Florence, Italy

Genet M, Kokutse N, Stokes A, Fourcaud T, Cai X, Ji J, Mickovski S (2008) Root reinforcement in plantations of Cryptomeria japonica D. Don: effect of tree age and stand structure on slope stability. For Ecol Manag 256(8):1517-1526

Gerhards CC, Link CL (1987) A cumulative damage model to predict load duration characteristics of lumber. Wood Fiber Sci 19(2):147-164

González-Ollauri A, Mickovski SB (2014) Integrated model for the hydro-mechanical effects of vegetation against shallow landslides. EQA-Int J Environ Qual 13(13):37-59

Jaky J (1948) Pressure in silos. In: Proceedings of the 2nd international conference on soil mechanics and foundation engineering, vol 1, pp 103-107

Juliszewski T, Kwaśniewski D, Pietrzykowski M, Tylek P, Walczyk J, Woś B, Likus J (2015) Root biomass distribution in an energy willow plantation. Agric Eng 19(4):43-49

Laio F, D'Odorico P, Ridolfi L (2006) An analytical model to relate the vertical root distribution to climate and soil properties. Geophys Res Lett 33(18):L18401

Li X, Zhang L, Zhang Z (2006) Soil bioengineering and the ecological restoration of riverbanks at the Airport Town, Shanghai, China. Ecol Eng 26(3):304-314 
Mickovski SB, Hallett PD, Bengough AG, Bransby MF, Davies MCR, Sonnenberg R (2008) The effect of willow roots on the shear strength of soil. Adv GeoEcol 39:247-262

Murphy J, Ellingwood B, Hendickson E (1987) Damage accumulation in wood structural members under stochastic live loads. Wood Fibre Sci 19(4):453-463

Pollen N, Simon A (2005) Estimating the mechanical effects of riparian vegetation on stream bank stability using a fiber bundle model. Water Resour Res 41(7):1-11

Pollen-Bankhead N, Simon A (2009) Enhanced application of rootreinforcement algorithms for bank-stability modeling. Earth Surf Proc Land 34(4):471-480

Preti F, Dani A, Laio F (2010) Root profile assessment by means of hydrological, pedological and above-ground vegetation information for bio-engineering purposes. Ecol Eng 36(3):305-316

Rosowsky DV, Bulleit WM (2002) Load duration effects in wood members and connections: order statistics and critical loads. Struct Saf 24(2-4):347-362

Schenk HJ (2008) The shallowest possible water extraction profile: a null model for global root distributions. Vadose Zone J 7(3):1119-1124

Simon A, Collison AJ (2002) Quantifying the mechanical and hydrologic effects of riparian vegetation on streambank stability. Earth Surf Proc Land 27(5):527-546

Smyth CE, Kurz WA, Neilson ET, Stinson G (2013) Nationalscale estimates of forest root biomass carbon stocks and associated carbon fluxes in Canada. Global Biogeochem Cycles 27(4):1262-1273

Stokes A, Atger C, Bengough AG, Fourcaud T, Sidle RC (2009) Desirable plant root traits for protecting natural and engineered slopes against landslides. Plant Soil 324(1-2):1-30

Tan Y (2005) Sheet pile wall design and performance in peat. Doctoral thesis, Univ. of Massachusetts-Lowell, Lowell, Mass

Tardío G, Mickovski SB (2016) Implementation of eco-engineering design into existing slope stability design practices. Ecol Eng 92:138-147

Thomas RE, Pollen-Bankhead N (2010) Modeling root-reinforcement with a fiber-bundle model and Monte Carlo simulation. Ecol Eng 36(1):47-61

Tron S, Laio F, Ridolfi L (2014) Effect of water table fluctuations on phreatophytic root distribution. J Theor Biol 360:102-108

Tron S, Perona P, Gorla L, Schwarz M, Laio F, Ridolfi L (2015) The signature of randomness in riparian plant root distributions. Geophys Res Lett 42(17):7098-7106
Van de Kuilen JWG (1999a) Duration of load effects in timber joints, $\mathrm{PhD}$. Thesis, Delft University of Technology, The Netherlands

Van de Kuilen JWG (1999) The residual load carrying capacity of timber joints. Heron 44(3):187-214

Van de Kuilen JWG (2007) Service life modelling of timber structures. Mater Struct 40(1):151-161

Van de Kuilen JWG, Blass HJ (2005) Mechanical properties of azobé (Lophira alata). Holz Roh- Werkst 63:1-10. https://doi. org/10.1007/s00107-004-0533-7

Van de Kuilen JWG, Gard WF (2012) Residual service life estimation using damage accumulation models. In: World conference on timber engineering, Auckland, New Zealand, 15-19 July 2012

Van de Kuilen JWG, Van Der Linden MLR (1999) Reliability based design of timber sheet pile walls. N Z Timber Des J 11(1):11-16

Van der Put TACM (1986) A model of deformation and damage processes based on the reaction kinetics of bond exchange. In: CIBW18 timber structures, proceedings of the 19th meeting, Paper 19-9-3, Florence, Italy

Van der Put TACM (1989) Deformation and damage processes in wood. PhD thesis, Delft University of Technology, Delft, The Netherlands

Visschedijk MAT, Trompille V (2011) D-Sheet piling Version 9, design of diaphragm and sheet pile walls. Deltrares, Delft

Wu TH, McKinnell WP III, Swanston DN (1979) Strength of tree roots and landslides on Prince of Wales Island, Alaska. Can Geotech J 16(1):19-33

Zeng F, Bleby TM, Landman PA, Adams MA, Arndt SK (2006) Water and nutrient dynamics in surface roots and soils are not modified by short-term flooding of phreatophytic plants in a hyperarid desert. Plant Soil 279(1-2):129-139

Zhang D, Cheng J, Liu Y, Zhang H, Ma L, Mei X, Sun Y (2018) Spatio-temporal dynamic architecture of living brush mattress: root system and soil shear strength in riverbanks. Forests 9(8):493

Publisher's Note Springer Nature remains neutral with regard to jurisdictional claims in published maps and institutional affiliations. 